prevention. In the mean time, careful clinical assessment and echocardiographic examination of patients undergoing prolonged parenteral nutrition is needed.

Nutrition Unit,

King's Cross Hospital,

Dundee

I Pithie AD, Pennington CR. The incidence, aetiology and management of central vein thrombosis during prolonged management of central vein thrombosis during

parenteral nutrition. Hum Nutr Clin Nutr (in press).
Messing B, Beliah M. Girard-Pipau F, et al. Technical hazards of

Messing B, Beliah M, Girard-Pipau F, et al. Technical hazards of
using nutritive mixes in bags for cyclical parenteral nutrition. using nutritive mixes in bags for cyclical parenteral nutrition.
Gut 1982;23:297-303.

3 Pithie AD, Main J, Soutar JS, Pennington CR. Catheter tip position and central vein thrombosis during parenteral nutrition. Hum Nutr Clin Nutr (in press).

\section{Extrapyramidal disturbances caused by inappropriate prescribing}

SIR,-We agree with the emphasis that Drs H S Pall and A C William placed on the importance of the side effects of extrapyramidal drugs (4 July, $p$ 30 ), but we would like to point out that drug induced Parkinson's disease, especially in the elderly, is not such a benign process as they suggested.

Firstly, the median period for the resolution of symptoms after drug treatment was stopped was seven weeks in the large study conducted by Stephen and Williamson, with a range of up to 36 weeks, ' and Marsden suggests that features of drug induced Parkinson's disease may persist for up to 18 months after drug treatment is stopped. ${ }^{2}$

Secondly, on reviewing the 48 patients described by Stephen and Williamson, we found that of those alive at a mean of $\mathbf{4 1}$ months after presentation, $25 \%$ who had undergone remission of drug induced Parkinson's disease subsequently developed idiopathic Parkinson's disease.

J A WILSON

Bangour General Hospital

West Lothian EH526LR

W R PrIMrose

Woodend General Hospital,

Aberdeen

I Stephen PJ, Williamson J. Drug induced parkinsonism in the elderly. Lancet 1984; ii: 1082-3.

2 Marsden CD, Jenner $P$. The pathophysiology of extrapyramidal side effects of neuroleptic drugs. Psychol Med 1980;10:55-72. 3 Wilson JA, Primrose WR. Drug induced parkinsonism. BrMed $\mathcal{J}$ 1986;293:957.

\section{Delivery after caesarean section}

SIR, - With reference to the study by Dr B G Molloy and colleagues (27 June, $p$ 1645) on vaginal delivery after one previous caesarean section, I would like to make these points.

Firstly, labour requiring acceleration with oxytocin was associated with an increased risk of repeat caesarean section, whereas labour induced with oxytoxin (and simultaneous amniotomy) was not. The opposite might more reasonably have been expected unless the selection for induction was based ultimately on a previously beneficial obstetric experience-namely, progression beyond $4 \mathrm{~cm}$ cervical dilatation. The $22 \%$ oxytocin acceleration of spontaneous labour further implies this selection. Therefore, to say without qualification that the induction of labour does not increase the risk of repeat caesarean section disguises the process of judicious selection that seems to have taken place and denies the study's own findings.

Secondly, in the cases of uterine scar rupture (in particutar those associated with oxytocin acceleration and epidural analgesia) was the duration of labour (in particular the duration of the second stage), the cumulative dose of oxytocin, or instrumental vaginal delivery related to this outcome?

Finally, what was the rate of instrumental delivery in the study group compared with the hospital population?

Dublin

Christopher FitzPatrick

AUTHORS' REPLY - The rate of instrumental delivery was $11.6 \%$ in the study group and $8.0 \%$ in the hospital population. This difference is not surprising as it is our practice to limit the duration of the second stage of labour in women who have had a previous caesarean section. No correlation was found between the duration of labour, the cumulative dose of oxytocin, or the instrumental vaginal delivery rate and the incidence of uterine rupture; indeed, all the ruptures occurred during the first stage of labour so that there were no instrumental deliveries at all.

We are surprised that Dr Fitzpatrick compares the incidence of caesarean section in spontaneous labour requiring augmentation with that in induced labour. These groups are quite different, and a direct comparison is invalid. An increased incidence of caesarean section among spontaneous accelerated labours has previously been reported, ${ }^{1}$ and we ourselves have shown that no correlation existed between labour and the rate of caesarean section. $^{3}$ Dr Fitzpatrick's suggestion that the opposite might more reasonably have been expected is quite incorrect.

In our paper we reported that 49 elective sections were performed because labour could not be induced. Previous progression beyond $4 \mathrm{~cm}$ dilatation was not the deciding factor in inducing labour. Furthermore, the $19 \cdot 2 \%$ incidence of induced labour in the study group was similar to the $19.8 \%$ incidence in the hospital population at the time. We reiterate our opinion that "induction of labour, in the manner described, does not increase the risk of caesarean section or uterine rupture." Dr Fitzpatrick seems to have overlooked the qualification "in the manner described," which takes account of the 49 patients who were unsuitable for induction.

N M DUIGNAN O SHEIL

University College Dublin,

Dublin 8

1 Studd JWW, Clegg D, Saunders RR, Hughes AO. Identification of high risk labours by nomogram. BrMed f 1975 ;ii:545. 2 Gibb DMF, Cardozo LD, Studd JWW, Magos AL, Cooper DJ Outcome of spontaneous labour in multigravidae. $\mathrm{Br} \mathcal{F}$ Obstet Gynaecol 1982;89(9): 708 .

3 Duignan NM. Coombe Lying-In Hospital annual report. Dublin Cahill Printers, 1984:87.

\section{Drinking and driving: success of random} breath testing in Finland

SIR,-Experience of controlling the drink driving problem in Finland, as described by J A Dunbar and colleagues (11 July, p 101), provides yet another example of the effectiveness of high visibility random breath testing and the degree of public acceptability with which this is usually met.

This evidence, together with the results of evaluation studies in Australia and the United States, has convinced us that unless British road users' perception of the chance of being detected with excess alcohol in the bloodstream is increased substantially there is little hope of real progress in reducing our drinking and driving problem.

The comments made by the Minister of Roads and Traffic in the House of Commons recently about the importance of changing public attitudes were well intentioned, but have we learnt nothing from the compulsory seat belt wearing experience? Surely, the lessons learnt from years of exhorting car occupants to don a seat belt, to little effect until they were forced to do so by law, should convince him of the benefits of legislation in reinforcing sympathetic public attitudes to safe practice.

An all party campaign for the introduction of random breath testing was launched formally with the tabling of an early day motion in the House of Commons in July. As with efforts to put seat belts on the statute book, the interest and support of the medical profession will be vital in securing the introduction of this proved means of reducing casualties.

BARRY SHEERMAN

Parliamentary Advisory Council for

Transport Safety,

London SW7 2BU

\section{The wide range of chlamydial infection}

SIR,-Perhaps because it was published 80 years ago, in German, and in a fairly inaccessible journal, the classic description by Halberstaedter and von Prowazek of chlamydial inclusions ${ }^{1}$ is often misquoted; this is a pity because it is a little masterpiece of early microbiological observation. Some points in Dr D Reid's leading article (18 July, p 156) must therefore be corrected.

Halberstaedter and von Prowazek did not think that chlamydiae were protozoans, nor did they call them chlamydozoaceae. They said, in translation: "All the pathogens mentioned [that is, viruses and what we now call chlamydia] have nothing in common with the bacteria.... There is however no ground for classifying them with the protozoa We therefore propose grouping them [chlamydiae] between both classes under the name Chlamydozoa."

Though the "zoa" component proved to be incorrect, the term chlamydia itself is not a misnomer, as stated by Dr Reid. From their description, it is clear that Halberstaedter and von Prowazek derived this part of their name from the Greek chlamys, a mantle, because of the blue staining material enveloping the elementary bodies (and not, as I have seen stated in another article on chlamydiae, because the origins of these infections are cloaked in obscurity).

It is noteworthy that the erroneous statements in the article by Dr Reid derive from those in an earlier paper by Ward, which is cited in the references. ${ }^{2}$ With respect, I suggest that this example (and there are many others) illustrates the importance of consulting original texts.

\section{Leslie Collier}

London NW3 2R

1 Halberstaedter L, von Prowazek S. Über Zelleinschlüsse parasitärer Natur beim Trachom. Arbeiten aus dem Kaiserlichen Gesundheitsamte. (Berlin, Deutschland) 1907;26:44-7.

Ward ME. Chlamydial classification, development and structure. Br Med Bull 1983;39:109-15.

\section{Correction}

\section{Doctors and the death penalty}

In this letter from the Danish section of Amnesty International (27 June, p 1692) the authors invited correspondence from fellow health workers on the problems of the death penalty, but their full address was not given. Correspondence should be addressed to: Amnesty International, Danish Section Medical Groups, Frederiksborggade 1, DK-1360 Copenhagen K, Denmark. 